\title{
Potential Hazards of Air Pollution on Environment, Health and Agriculture
}

\author{
Sushan Chowhan* \\ Bangladesh Institute of Nuclear Agriculture, Bangladesh \\ Submission: April 19, 2021; Published: May 25, 2021 \\ *Corresponding author: Sushan Chowhan, BINA Sub-station, RARS campus (behind ATI, Aronkhola), Ishurdi, Pabna-6620, Bangladesh
}

\section{Abstract}

Air is an essential element of the earth's atmosphere. Modern civilization and industrialization have rapidly changed the world and also uplifted the rate of different environmental pollutions. The serious consequences of air pollution cannot be ignored as it is related to maintain all sorts of life on earth. This article reviews the possible threat of air pollution on environment, health and crop production. During 2020, out of top 50 air polluted cities around the globe, 49 were from Bangladesh, China, India, and Pakistan. Intensity of $\mathrm{PM}_{2.5}$ and $\mathrm{PM}_{10}$ at various region of Bangladesh were $56.22-210.45 \mu \mathrm{g} / \mathrm{m}^{3}$ and $163.41-316.31 \mu \mathrm{g} / \mathrm{m}^{3}$ respectively. $\mathrm{PM}_{2.5}$ was superiorly $(58 \%)$ responsible for air pollution in Dhaka city. Level of different air pollutants $\left(\mathrm{PM}, \mathrm{NO}_{x^{\prime}} \mathrm{SO}_{2}, \mathrm{CO}, \mathrm{O}_{3}\right.$ ) relied on activity, time and seasonal variation. COVID-19 pandemic significantly decreased PM emissions nearly 28\% in Malaysia, 75\% in Morocco and around 21\% in China. Numerous serious health risk of air pollution was observed; among them death from cardio vascular (32.77\%), cancers (10.49\%) and respiratory diseases (10.21\%) was main. $\mathrm{SO}_{2}, \mathrm{NO}_{\mathrm{x}^{\prime}}$ fluorides and $\mathrm{O}_{3}$ were noted to be the key pollutants to hamper crop adaptation to stress and also reduce the production. Yield reduction of rice (about $15 \%$ ), corn (nearly 20\%) and wheat (almost $40 \%$ ) was significant in an increased concentration of $\mathrm{O}_{3}$. Some prime remedy to control and minimize air pollutions were remarked as- improvement of public transportation system, shifting industries and brick kilns away from urban areas, setting and using waste treatment plant in industries, using ecofriendly green technologies, raising public awareness on air pollution through mass and social medias, enforcing environment pollution law by the government. Air pollution control and reduction requires a combination of many approaches; it is high time to take necessary action to stop and prevent air pollution now; else our future generation will suffer endlessly.

Keywords: Air pollution; $\mathrm{AQI} ; \mathrm{PM}_{2.5} ; \mathrm{PM}_{10} ; \mathrm{SO}_{x^{\prime}} ; \mathrm{NO}_{\mathrm{x}} ; \mathrm{O}_{3} ;$ Air pollution induced crop yield; Bangladesh

\section{Introduction}

Air is the inseparable physical part of earth's atmosphere and so much important to maintain life and ecosystem. Major composition of air is nitrogen (78\%) and oxygen (21\%); rest are minor gases (mostly argon; along with trace amounts of carbon dioxide, methane, hydrogen, helium etc.) which comprises approximately $1 \%$ of the total air [1]. Constitution of air is balanced in such a way that is favorable for all living beings of the planet and the atmospheric chemistry is vastly reliant on the living organisms in the biosphere [2]. Unlike other planets in the solar system life is impossible mainly due to air composition and temperature. Constituents of air largely depends on temperature i.e., air temperature which is directly related with warming or cooling of a location. Increase or decrease of earth's temperature is natural process but, human emissions of various gases play a significant role [3]. More the gas molecules move more quickly the air temperature increases and vice versa. Any serious alteration in the air configuration accelerates changes in environment and its elements. Environmental pollution is any discharge of material or energy into water, land or air that causes or may cause acute (short- term) or chronic (long-term) detriment to the earth's ecological balance or that lowers the quality of life [4]. Long term or stable state of modified air composition causes air pollution, which also contributes to global warming. The organization of earth's atmosphere altered remarkedly over time by human activities [5]. Fluctuations in environment are hurtful to human health, crops and ecosystems. While humans are the vital part of an ecosystem, the urban ecosystem is hostilely affected by several air pollutants like- particulate matter (PM) and hazardous air pollutants (HAPs) $[6,7]$. More than one-third of Bangladesh's population live in large urban areas. By 2050, at least half of the population will be urbanized [8]. The highest concentration of population growth has been in and around Dhaka (latitude $23.77^{\circ} \mathrm{N}$, longitude $90.38^{\circ} \mathrm{E}$ ), the capital of Bangladesh; which is one of the most densely populated cities in the world (ranked within the top 15), with a population density of approximately 28,000 per sq. $\mathrm{km}$ as per 2016 [9]. There has been an eightfold increase in population since 1970, and it now stands almost 22 million, making it the seventh largest city in the world [10]. Key air pollutants may be 
present in gaseous forms, particles in suspension, various ionizing radiation. Gaseous forms are mostly oxidized and reduced of carbon $\left(\mathrm{CO}_{2}, \mathrm{CO}, \mathrm{CH}_{4}\right)$, nitrogen $\left(\mathrm{NO}_{2}, \mathrm{NO}, \mathrm{N}_{2} \mathrm{O}_{4}, \mathrm{NH}_{3}, \mathrm{NH}_{4}^{+}\right), \mathrm{SO}_{2}, \mathrm{O}_{3}$, $\mathrm{C}_{6} \mathrm{H}_{6}$ vapors, $\mathrm{Hg}$, volatile phenols, $\mathrm{Cl}_{2}$, etc. Particulate forms are$\mathrm{PM}_{10}$ (particles diameter $\leq 10 \mu \mathrm{m}$ ) and $\mathrm{PM}_{2.5}$ (particles diameter $\leq 2.5 \mu \mathrm{m})$ particulate matter, heavy metals $(\mathrm{Pb}, \mathrm{Ni}, \mathrm{Cd}, \mathrm{As})$ with toxic effect, polycyclic aromatic hydrocarbons (PAH) etc. [4]. In South Asia, airborne particulate matter $\left(\mathrm{PM}_{10}\right.$ and $\left.\mathrm{PM}_{2.5}\right)$ is a major concern because of its high ambient concentrations and documented impact on morbidity and premature mortality [11]. Air pollution presently a major environmental concern in all large cities of the world including Dhaka city of Bangladesh [12]. In this mega city air pollution is widely occurred by emissions from road traffic [13], brick kilns, dust from roads, construction sites and toxic fumes from industries [14]. For instance, South East France as well as Dhaka city is one of the region's most influenced by atmospheric pollution [15]. However, particulate matter (PM) pollution is basically believed to be a major indicator of urban air quality and is linked to human health hazards [16]. On the other hand, air pollutants negatively affect crop production, yield and thereby involved ecosystems of beneficial insects, vertebrates etc. $[17,18]$.

Impact of air pollution is vast, complex and quite hard to quantify. Nearly it's impossible to stop or eradicate air pollution fully from the environment. With the pace of time human civilization has become modernized and machine dependent resulting enhanced pollution than earlier times. Thus, it's imperative to know about the air pollution to keep our environment clean and pollution free. Considering these situation, Table 1: Particulate matter $\left(\mathrm{PM}_{2.5}\right)$ emission factors ( $\mathrm{mg} / \mathrm{g}$ of fuel) from vehicles in Dhaka; Source: adapted from lqbal et al. [21] calculated based on EEA methodology [22]. a thorough review was done to briefly expose the main causes, areas, effects and remedies to control air pollution so that we can lead a healthy and sound life.

\section{Discussion}

\section{Causes and scenario of air pollution}

Air pollution is an emerging problem in many countries. Yet, attention to date has been on its impact on human health, environment and finally on food production. Out of 50 cities, 49 are from Bangladesh, China, India, and Pakistan which are most polluted. Currently Bangladesh is the top air polluted country $\left(77.1 \mu \mathrm{g} / \mathrm{m}^{3}\right)$ where $80 \%$ of it's cities are 'unhealthy' $>55.5 \mu \mathrm{g} /$ $\mathrm{m}^{3}$ ) as per US AQI (United States Air Quality Index) measurement. In terms of $\mathrm{PM}_{2.5}$ pollution, Dhaka holds the second position globally [19]. Cause of upsurge in pollution level in Dhaka is due to unplanned urbanization, industrialization, and motorization. Brick kiln operations in and around Dhaka are also liable for a large share of Dhaka's polluted air, which accounts for 58\% of total fine particulate matter $\mathrm{PM}_{2.5}$ pollution, followed by motor vehicles $(10.4 \%)$, road dust $(7.70 \%)$, fugitive $\mathrm{Pb}(7.63 \%)$, soil dust (7.57\%), biomass burning (7.37\%) and sea salt (1.33\%) [20]. DoE [12] observed, concentration level of $\mathrm{PM}_{2.5}$ and $\mathrm{PM}_{10}$ at different locations of Bangladesh were $56.22-210.45 \mu \mathrm{g} / \mathrm{m}^{3}$ and 163.41$316.31 \mu \mathrm{g} / \mathrm{m}^{3}$ respectively; AQI impression was unhealthy to extremely unhealthy along with few good, moderate and caution; most frequent responsible pollutant was $\mathrm{PM}_{2.5}$. Emission rate of $\mathrm{PM}_{2.5}$ from different types of vehicle was much higher which used diesel and lowest with CNG (Compressed Natural Gas) (Table 1).

\begin{tabular}{|c|c|}
\hline Fuel and Vehicle Type & $\mathrm{PM}_{2.5}$ Emissions (mg/g of Fuel) \\
\hline \multicolumn{2}{|c|}{ Gasoline } \\
\hline \multicolumn{2}{|l|}{ Passenger Car (Euro 2/Euro 4) } \\
\hline$<1.4 \mathrm{~L}$ & $1.125 / 0.02$ \\
\hline $1.4-2.0 \mathrm{~L}$ & $0.985 / 0.017$ \\
\hline$>2.0 \mathrm{~L}$ & $0.844 / 0.013$ \\
\hline LDV (Conventional/Euro 4) & $0.844 / 0.011$ \\
\hline $\mathrm{MC}(>50 \mathrm{cc})$ (Euro 2/Euro 4) & $7.032 / 0.097$ \\
\hline \multicolumn{2}{|c|}{ Diesel } \\
\hline LDV (conventional/Euro 3) & $5.889 / 0.879$ \\
\hline Truck < 7.5t (Euro 1/Euro 3) & $7.853 / 0.453$ \\
\hline Bus-urban midi (Euro 1/Euro 3) & $3.926 / 0.566$ \\
\hline \multicolumn{2}{|c|}{ CNG } \\
\hline Passenger Car (Euro 2/Euro 4) (all capacities) & $0.21 / 0$ \\
\hline LDV (>2.0L) (Euro 2/Euro 4) & $0.18 / 0$ \\
\hline HDV bus (Euro 4) & 0.018 \\
\hline $3 \mathrm{~W}(<1.4 \mathrm{~L})$ (Euro 2/Euro 4) & $0.21 / 0$ \\
\hline
\end{tabular}


Concentration of different air pollutant i.e. $\mathrm{PM}, \mathrm{NO}_{x^{\prime}} \mathrm{SO}_{2}, \mathrm{CO}$, $\mathrm{O}_{3}$ depends on human activities, time and seasonal variations. PM and $\mathrm{NO}_{\mathrm{x}}$ are reduced during weekends and national holidays. It was noticed that a declining trend of PMs occurred between time 13.00 to 17.00 hrs., lowest $\mathrm{SO}_{2}$ concentration between 13.00 to 15.00 hrs., minimum level of $\mathrm{NO}, \mathrm{NO}_{2}, \mathrm{NO}_{\mathrm{x}}$ at 12.00 to $17.00 \mathrm{hrs}$ whereas $\mathrm{O}_{3}$ intensity was lower from $1.00 \mathrm{hrs}$ to $10.00 \mathrm{hrs}$ then it had a up lining trend. Less CO was observed among 17.00 to 19.00 hrs. later it rose (Figure 1). Reduced movement during COVID-19 pandemic significantly decreased PM emissions by almost $28 \%$ in Malaysia [23], 75\% in Morocco [24] and about 21\% in China [25]. Battery industries of old Dhaka city contributing to the degraded air quality by recycling heavy metals ( $\mathrm{Pb}, \mathrm{Hg}$ etc.) in the open places [26].

Table 2: List of activities which produce the leading air pollutants. (DoE [28]).

\begin{tabular}{|c|c|}
\hline Activities/Sources & Pollutant \\
\hline $\begin{array}{l}\text { Motor vehicle exhaust, kerosene, power plants with internal combustion engines or wood/biomass burning } \\
\text { stoves. }\end{array}$ & Carbon Monoxide (CO) \\
\hline $\begin{array}{c}\text { Coal-fired power plants, brick kilns, petroleum refineries, sulphuric acid manufacture, and smelting sulphur } \\
\text { containing ores. }\end{array}$ & Sulphur Dioxide $\left(\mathrm{SO}_{2}\right)$ \\
\hline $\begin{array}{l}\text { Motor vehicles, power plants, and other industrial, commercial, and residential sources that burn fuels (e.g., } \\
\text { diesel generators). }\end{array}$ & Nitrogen Dioxide $\left(\mathrm{NO}_{2}\right)$ \\
\hline $\begin{array}{l}\text { Vehicle exhaust and certain other fumes (hydrocarbons). Formed from other air pollutants in the presence of } \\
\text { sunlight. }\end{array}$ & Ozone $\left(\mathrm{O}_{3}\right)$ \\
\hline Metal refineries, lead smelters, battery manufacturers, iron and steel producers. & Lead $(\mathrm{Pb})$ \\
\hline $\begin{array}{c}\text { Diesel engines, motor vehicles, power plants, brick kilns, industries, windblown and road dust, wood/ biomass } \\
\text { stoves, open burning. }\end{array}$ & Particulate Matter (PM) \\
\hline
\end{tabular}
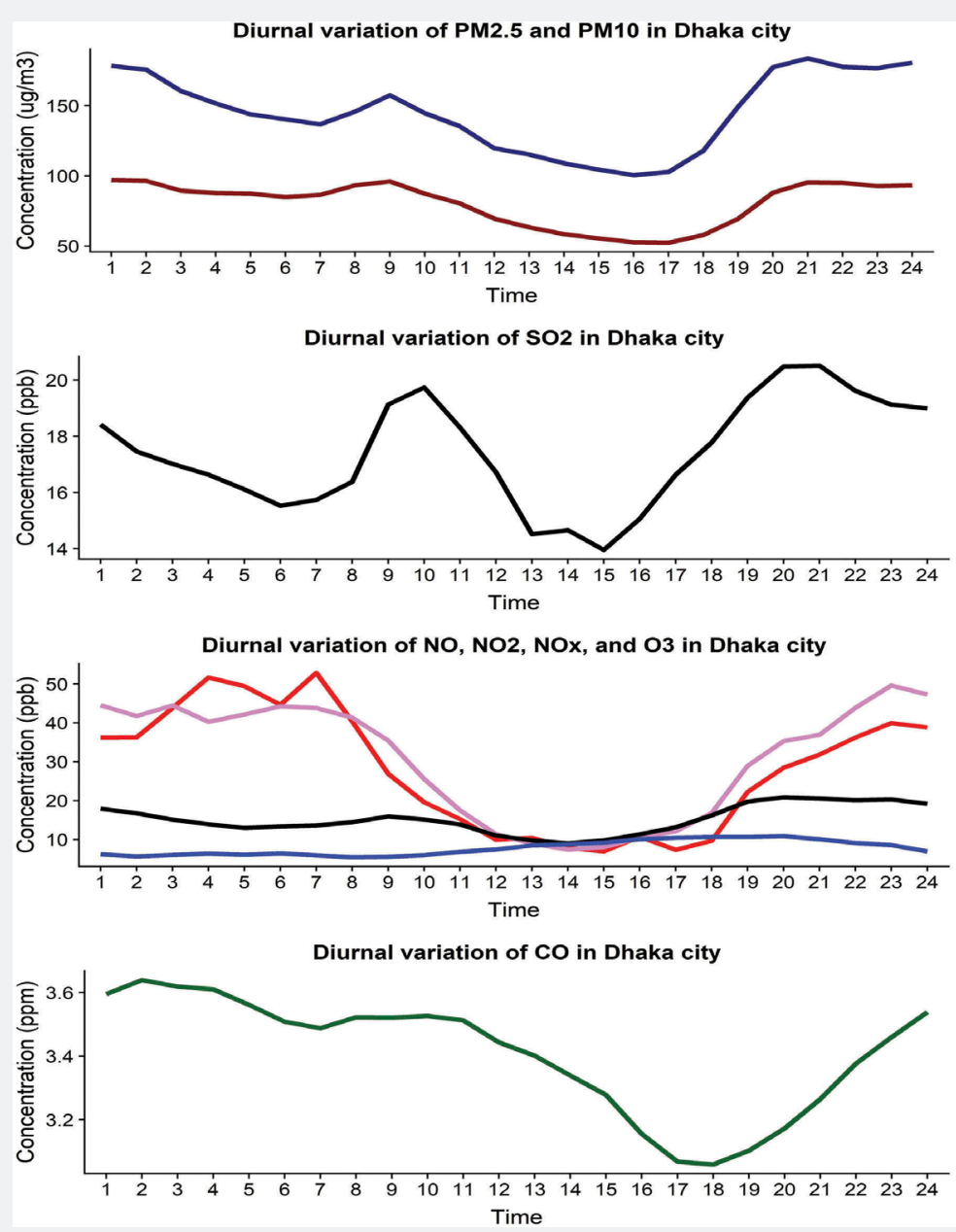

Figure 1: Diurnal variations of different pollutant level in Dhaka city during 2017. Source: Rahman et al. [27]. 
Major air pollution (Table 2) is produced from industry, agriculture, transports and urbanization. Hydrocarbon burning in motor engines escalates $\mathrm{CO}_{2}, \mathrm{CO}, \mathrm{SO}_{2}, \mathrm{NO}_{x^{\prime}} \mathrm{NO}_{2}$ and $\mathrm{C}_{2} \mathrm{H}_{4}$ in various fractions. Industrial plants of chemical works, metal smelting release $\mathrm{SO}_{2}, \mathrm{H}_{2} \mathrm{~S}, \mathrm{NO}_{2}$ and $\mathrm{HF}$ (hydrogen fluoride) in the air. Though tall chimney stacks discharge these gases to a high altitude to prevent local pollution, but these pollutants return to earth. Sometimes photochemical smog is produced by complex reaction of sunlight, $\mathrm{NO}_{\mathrm{x}}$ (from urban and industrial origin) and volatile organic compounds from either vegetation (biogenic hydrocarbons) or human activities (anthropogenic hydrocarbons) Ozone $\left(\mathrm{O}_{3}\right)$ and peroxyacetylnitrate (PAN). This smog can be deleterious to all living beings subjected to concentration and duration of exposure. Hydrogen peroxide $\left(\mathrm{H}_{2} \mathrm{O}_{2}\right)$, is another potentially harmful molecule generated through reaction of $\mathrm{O}_{3}$ and naturally released volatiles (terpenes) from forest trees. Nevertheless, intensity of detrimental gases are highly variable and depends on location, wind direction, rainfall, and sunlight. Pollutants emitted into the open air can react with constituents of the atmosphere and convert into more or less noxious compounds. Transformation of pollutants can also have indirect adverse effects on ecosystem biocoenosis, plants, animals and human health (Figure 2) [4].

\section{Health impacts}

A wide range of air pollutants are primely responsible for occurring various fatal disease in humans. Amongst them, PMs, enter the respiratory system through inhalation causing respiratory and cardiovascular disorders, reproductive problems, neuron dysfunctions and cancer. Despite the fact that $\mathrm{O}_{3}$ in the stratosphere defend us against ultraviolet irradiation but, it's high concentration at ground is unsafe as it affects the respiratory and cardiovascular system. Furthermore, nitrogen oxide $\left(\mathrm{NO}_{\mathrm{x}}\right)$, sulfur oxide ( $\mathrm{SO}_{\mathrm{x}}$ ), Volatile Organic Compounds (VOCs), dioxins,

Table 3: Varieties of disorders caused by air elements. Source: DoE [28] \& Alam et al. [31]. and polycyclic aromatic hydrocarbons (PAHs) are all considered air pollutants that are dangerous to humans. Breathing Carbon monoxide (CO) in high levels can be poisonous. Absorption of lead $(\mathrm{Pb})$ like heavy metals in body can result direct poisoning or chronic intoxication depending on exposure. Diseases occurring from the aforementioned substances include predominantly respiratory difficulties such as Chronic Obstructive Pulmonary Disease (COPD), asthma, bronchiolitis, and also lung cancer, cardiovascular events, central nervous system dysfunctions and cutaneous diseases. Environmental pollution ensuring climate change affects the global dispersal of several infectious diseases [29]. Air pollution is highly considered to be associated with the above-mentioned health complexities [30].

Earlier findings (Table 3) denotes that, higher level of exposure and concentration of Nitrogen oxide $\left(\mathrm{NO}_{\mathrm{x}}\right)$, Sulphur Dioxide $\left(\mathrm{SO}_{\mathrm{x}}\right)$, Carbon Monoxide (CO), Carbon dioxide $\left(\mathrm{CO}_{2}\right)$, Volatile Organic Carbon (VOC), Oxygen $\left(\mathrm{O}_{2}\right)$, Ozone $\left(\mathrm{O}_{3}\right)$, Lead $(\mathrm{Pb})$, Particulate Matter (PM), Suspended Particulate Matter (SPM), Relative Humidity (RH), Hydrogen Sulfide $\left(\mathrm{H}_{2} \mathrm{~S}\right)$ negatively effects human body and organs [28,31]. Extreme air pollution is attributed to cardiovascular disease (CVD), asthma, stroke, COPD, acute lower respiratory infections in children and lung cancer [32]. Maximum mortality in Bangladesh is occurred by cardiovascular disease, followed by cancers, respiratory disease and diabetes (Figure 3). Research findings indicate that increased death from CVD and respiratory diseases in Bangladesh were mainly due to more exposure to fine particulate matter mass [33]. Rest causes were found to be excessive smoking, changes in food habit, lifestyle and physical fitness [34]. High blood pressure, smoking and outdoor air pollution ranked first, second and third risk factors respectively for mortality in Bangladesh [35,36]. In 2015, over 120,000 people died because of peak exposure to $\mathrm{PM}_{2.5}$ [37]. Thus, an increasing trend in death level was noticed from the year 2000 to 2015 (Figure 4).

\begin{tabular}{|c|c|c|}
\hline SL. & Air Element/Pollutants & Health Related Problems \\
\hline 1 & Nitrogen oxide $\left(\mathrm{NO}_{\mathrm{x}}\right)$ & $\begin{array}{l}\text { Lung disorders and susceptibility to respiratory infections, irritation of the lung and respiratory symp- } \\
\text { toms (e.g., cough, chest pain, difficulty in breathing). }\end{array}$ \\
\hline 2 & Sulphur Dioxide $\left(\mathrm{SO}_{\mathrm{x}}\right)$ & Eye irritation, wheezing, chest tightness, shortness of breath, lung damage. \\
\hline 3 & Carbon Monoxide (CO) & $\begin{array}{l}\text { Reduction of oxygen carrying capacity in blood. headaches, reduced mental alertness, heart attack, cardio- } \\
\text { vascular diseases, impaired fetal development, death. }\end{array}$ \\
\hline 4 & Carbon dioxide $\left(\mathrm{CO}_{2}\right)$ & $\begin{array}{l}\text { Cardio vascular diseases, impaired blood circulation, equilibrium concentration of oxygen in blood reduc- } \\
\text { es hemoglobin and damage to the nervous system. }\end{array}$ \\
\hline 5 & Volatile Organic Carbon (VOC) & $\begin{array}{l}\text { Irritation of eyes, nose and throat, headaches, loss of coordination, damage to kidneys, liver and central } \\
\text { nervous system (neo-natal), skin cancer (human and animal), and skin allergy. }\end{array}$ \\
\hline 6 & Oxygen $\left(\mathrm{O}_{2}\right)$ & High flow of oxygen causes death (neo-natal) damage to the brain \\
\hline 7 & Ozone $\left(\mathrm{O}_{3}\right)$ & $\begin{array}{l}\text { Eye and throat irritation, coughing, respiratory tract problems, asthma, lung damage, leading to prema- } \\
\text { ture mortality. }\end{array}$ \\
\hline 8 & Lead $(\mathrm{Pb})$ & $\begin{array}{c}\text { Anemia, high blood pressure, brain and kidney damage, neurological disorders, cancer, lowered IQ. mis- } \\
\text { carriage, osteoporosis }\end{array}$ \\
\hline 9 & Particulate Matter (PM) & $\begin{array}{c}\text { Bronchitis, chronic cough, corrodes and irritates the alveolar wall, respiratory disease, asthma ultimately } \\
\text { leading to premature mortality. }\end{array}$ \\
\hline
\end{tabular}




\section{International Journal of Environmental Sciences \& Natural Resources}

\begin{tabular}{|c|c|c|}
\hline 10 & $\begin{array}{c}\text { Suspended Particulate Matter } \\
\text { (SPM) }\end{array}$ & Causes eye irritation, allergy, rhinitis, asthma, droplet infection of teeth. \\
\hline 11 & Relative Humidity (RH) & $\begin{array}{c}\text { High relative humidity causes asthma, allergies, low blood pressure, low relative humidity can dry out and } \\
\text { inflame the mucus membrane lining the respiratory tract, increased risk of flu, irritated sinuses. }\end{array}$ \\
\hline 12 & Hydrogen Sulfide $\left(\mathrm{H}_{2} \mathrm{~S}\right)$ & Creates a bad odor, causes nausea, throat irritation, and bacterial infection. \\
\hline
\end{tabular}

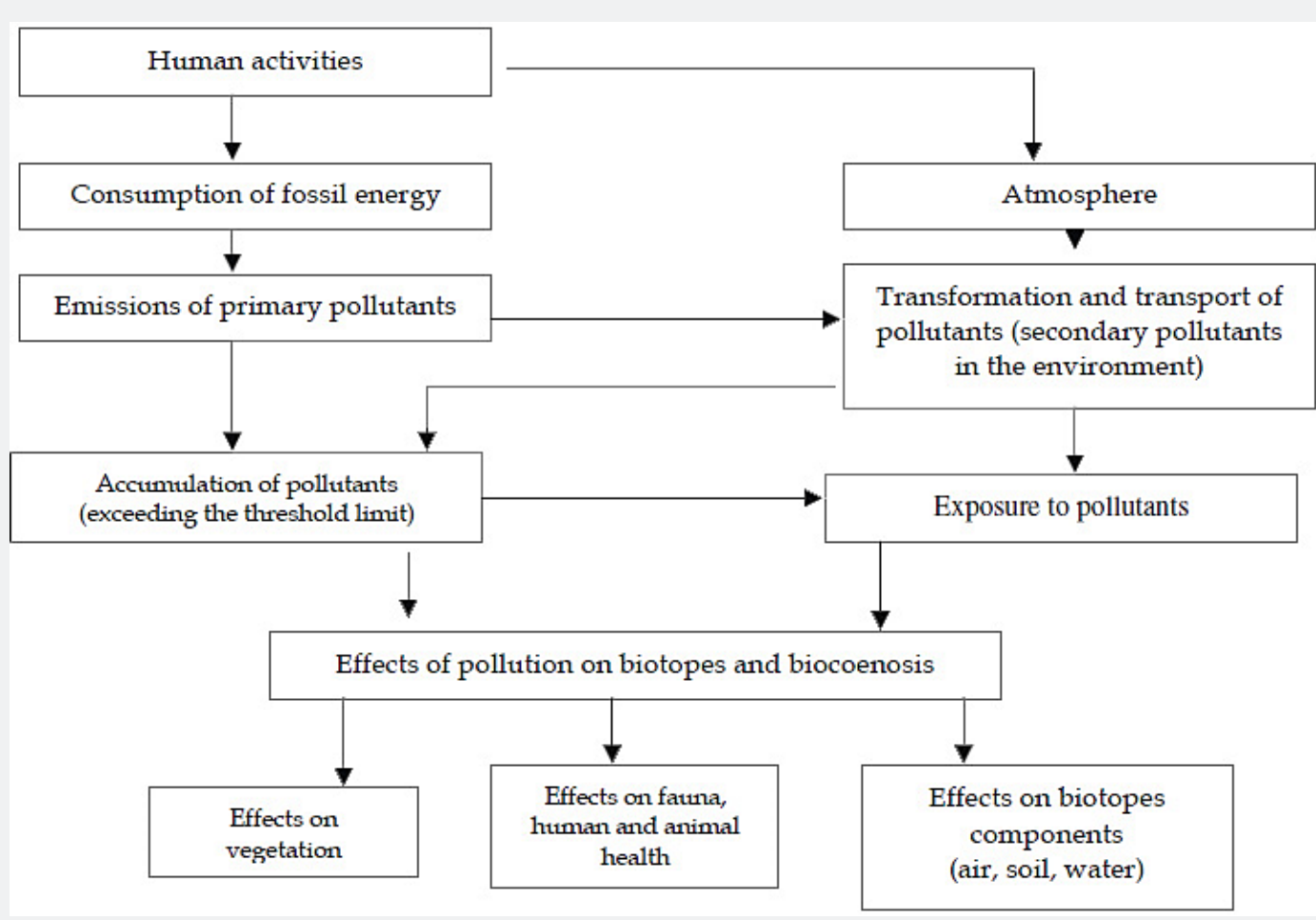

Figure 2: Flow diagram of air pollution.

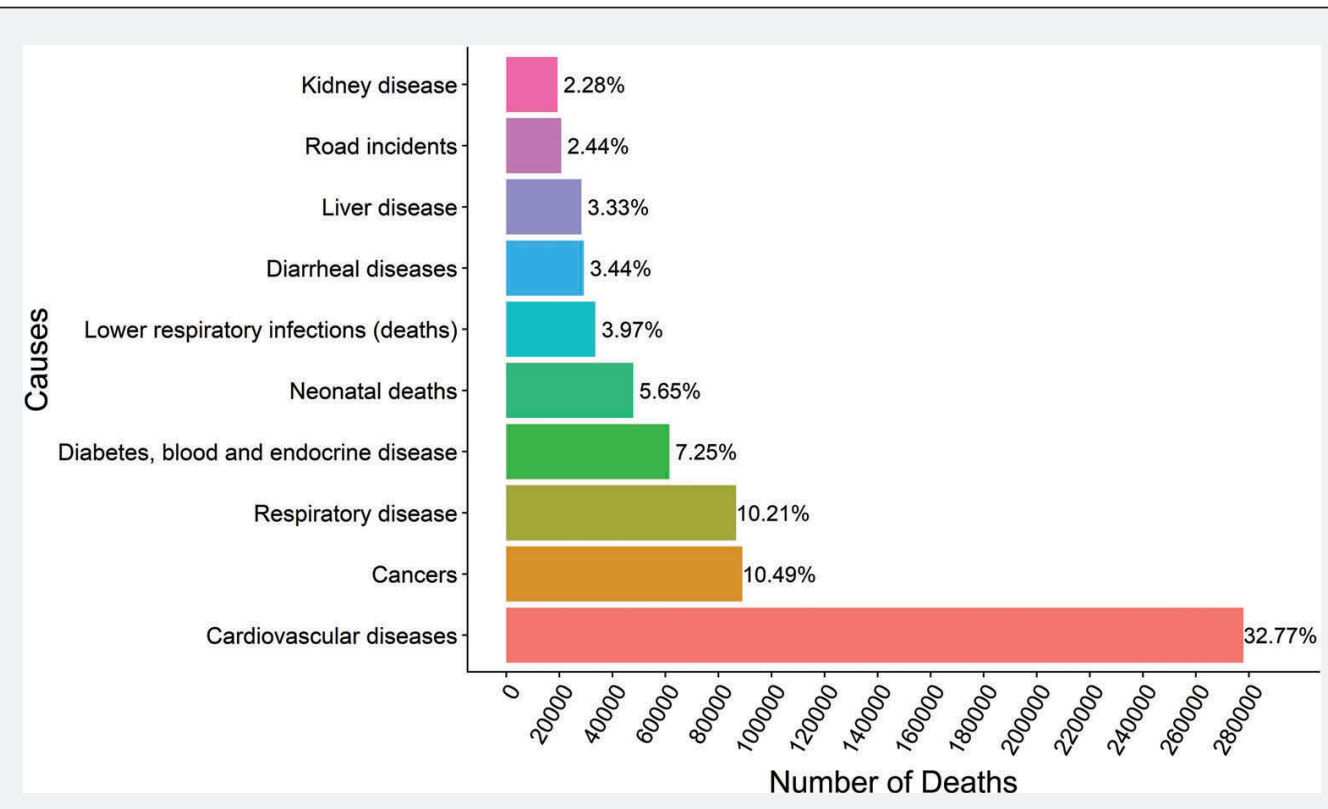

Figure 3: Yearly deaths caused by top ten diseases in Bangladesh [35]. 


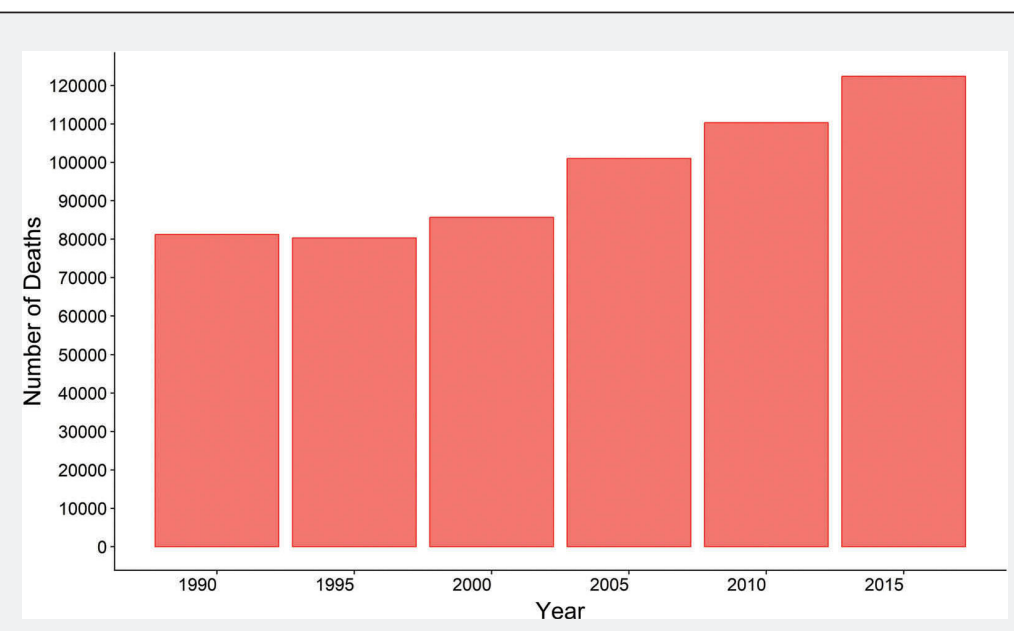

Figure 4: Trend of mortality through $\mathrm{PM}_{2.5}$ exposure in Bangladesh. Source: Health Effects Institute [37].

Table 4: Changes in crop plants with the effect of air pollutants. Source: Devrajani et al. [39] \& Eris et al. [40].

\begin{tabular}{|c|c|}
\hline Pollutant & Symptom and Effects \\
\hline \multirow{9}{*}{$\mathrm{SO}_{2}$} & $\mathrm{SO}_{2}$ enters the leaves mainly through the stomata. \\
\hline & Causes general water stress in plants by reducing stomatal opening. \\
\hline & Changes the membrane permeability by affecting structural proteins in the cell membrane. \\
\hline & Reduces the synthesis of proteins and enzymes by interfering with amino acid metabolism. \\
\hline & Inactivates many enzymes either by breaking their S-S bonds or by changing their stereo structure. \\
\hline & Reduces photosynthesis and increases respiration. \\
\hline & Exposed leaves can begin to lose their color in irregular, blotchy white spots. Some leaves can develop red, brown or black spots. \\
\hline & $\begin{array}{l}\text { When the pigments in enough tissue are damaged or killed, plants can begin to lose their leaves. Crop output is greatly reduced and } \\
\text { growth can be stunted. This is especially noticeable in young plants. }\end{array}$ \\
\hline & Bleached spots, Chlorosis, Chronic injury occurs in spinach and other leafy vegetables \\
\hline \multirow{6}{*}{$\mathrm{NO}_{\mathrm{x}}$} & $\begin{array}{l}\text { Reduced photosynthesis: } \mathrm{NO}_{2} \text { causes formation of crystalloid structures in the stroma of chloroplasts and swelling of thylakoid } \\
\text { membrane. }\end{array}$ \\
\hline & Chlorosis in leaves: most of the angiosperm species produce water-soaked intravenous areas that later become necrotic. \\
\hline & $\mathrm{NO}_{2}$ mostly affects the leaves and seedlings. Reduced photosynthesis ultimately leads to the reduction in yields. \\
\hline & Increased abscission and reduced yield in citrus plants \\
\hline & Suppressed growth of tomatoes \\
\hline & Spots of mild necrosis on cotton, bean plants and acute leaf injury \\
\hline \multirow{4}{*}{ Fluorides } & Acute symptoms of tip necrosis, occasionally with a reddish-brown band. \\
\hline & The chronic symptoms include leaf yellowing and mottling. \\
\hline & $\begin{array}{c}\text { Rice glumes are affected, showing tip necrosis with dark brown band. If the glumes are severely affected, no grains will be formed. } \\
\text { Dead tips of leaves and glumes become white or greyish white. }\end{array}$ \\
\hline & $\begin{array}{l}\text { Fluoride affects almost all the biochemical and physiological process of the plant and causes serious damage to the plant. These } \\
\text { effects ultimately lead to the reduction in yield. }\end{array}$ \\
\hline \multirow{5}{*}{$\mathrm{O}_{3}$} & $\mathrm{O}_{3}$ enters the leaves through the stomatas and cause visible injury to the leaves (Fleck on upper surface). \\
\hline & $\begin{array}{l}\text { It destroys rubisco resulting reduced photosynthesis by decomposing outer membrane of chloroplast thus chlorophyll and proteins } \\
\text { related to photosynthesis decreased. }\end{array}$ \\
\hline & Necrosis and bleaching; damage to tobacco \\
\hline & $\begin{array}{l}\text { Reduced carbon uptake caused by reduced photosynthesis lead to lowered carbon transport to roots, the growth of root is inhibited } \\
\text { and consequently less nutrients will be assimilated from the ground, as a result the growth rate of rice is decreased. }\end{array}$ \\
\hline & Results in accelerated aging of crops. \\
\hline
\end{tabular}




\section{Consequences on crop production}

Apart from destruction of human health air pollutants are also damaging the yield of food crops, their nutritional quality and safety, imposing a major risk to food security. As per report of 2014, air pollution has decreased the yields of wheat and rice by half in India. Researchers mostly ascribe this to ground level $\mathrm{O}_{3}$. Notably between 1980 and 2010 yields were up to $36 \%$ lower than what would have been without air pollution trends [38].

Latest research investigations indicate that, crop production is seriously hampered by a number of air pollutants (sulphur dioxide $\left(\mathrm{SO}_{2}\right)$, Nitrogen oxides $\left(\mathrm{NO}_{\mathrm{x}}\right)$, and Ozone $\left(\mathrm{O}_{3}\right)$. These pollutants create reactive oxygen species (ROS), which negatively affect biochemical activities of plants and decrease their adaptive capacity stresses. Some imperative physiological processes like- photosynthetic $\mathrm{CO}_{2}$ fixation and energy metabolism are also affected by the pollutants. Impact of air pollutants depends not only upon its concentration, but also on the duration and composition of air pollutants. Ozone is the most phytotoxic element among the available air pollutants [39]. A list of common air pollutants and their influence and morphological symptoms on plant are described in Table 4.

Atmospheric particulate matter (PM) can enhance crop production through the redistribution of light from sunlight to shaded leaves. Nitrogen transported through the atmosphere can also increase crop production when deposited onto cropland by reducing nutrient limitations in these areas [41].

Air pollution induced climate change can trigger some crop's production and can halt particulars yield. HYV aus, aman, boro and wheat production was found to be highest at $660 \mathrm{ppmv} \mathrm{CO}_{2}+00^{\circ} \mathrm{C}$. Wheat biomass and grain yield was maximum noted with $550 \mathrm{ppm}$ $\mathrm{CO}_{2}$ concentration. Most of $\mathrm{C}_{4}$ crops will be benefited by increased $\mathrm{CO}_{2}$ intensity in terms of yield and biomass production as they bear kranz anatomy in the vascular tissues and have better efficacy to utilize the extra $\mathrm{CO}_{2}$ during photosynthesis [43]. Yield loss of rice (about 15\%), corn (about 20\%) and wheat (about 40\%) enhanced when amount of $\mathrm{O}_{3}$ concentration was increased (Figure 5).
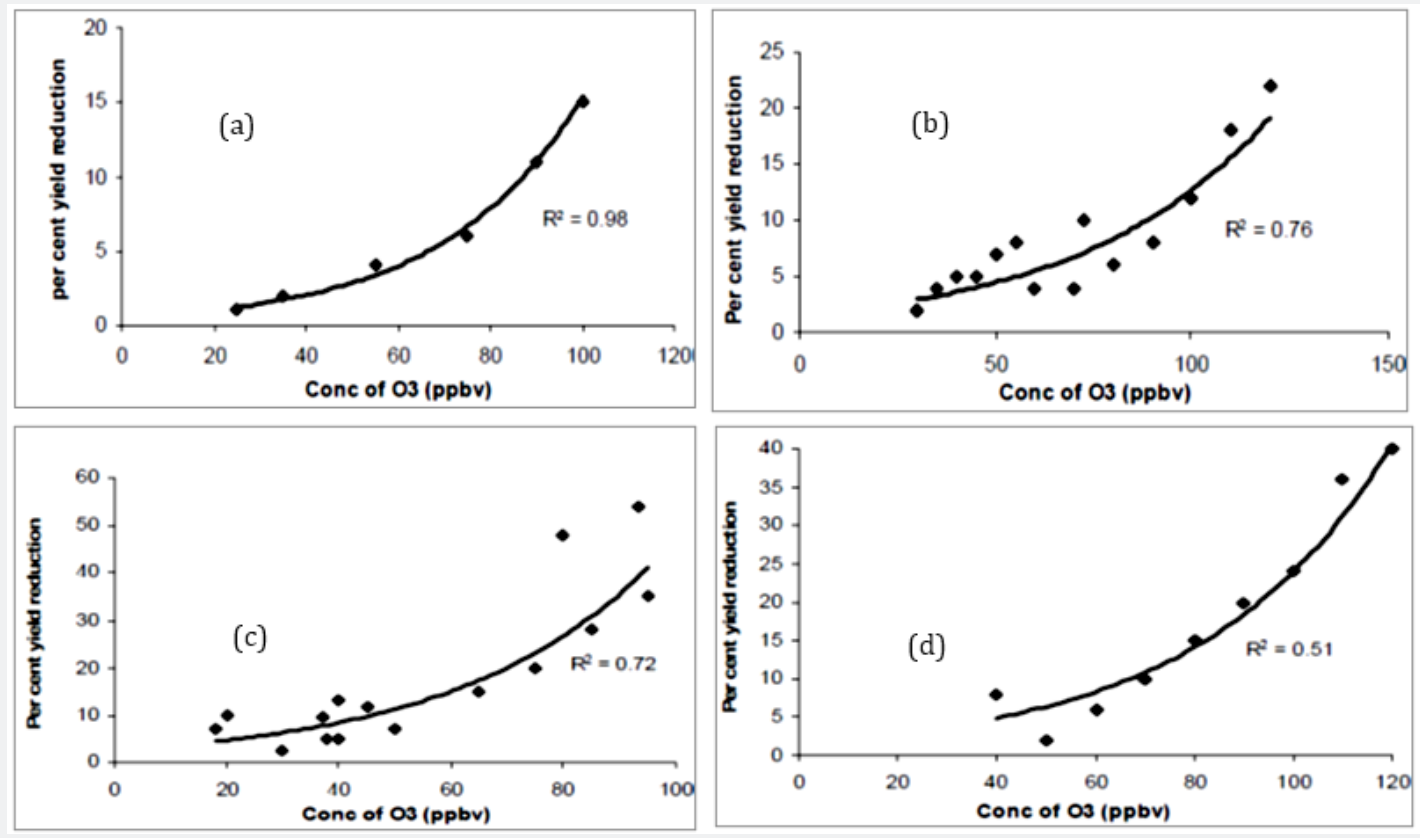

Figure 5: Yield reduction of (a) rice, (b) corn, (c) spring wheat and (d) winter wheat with varied $\mathrm{O}_{3}$ levels [42].

\section{Probable solutions to minimize air pollution}

Complete eradication of air pollution is not possible but by taking and doing certain initiatives and works we can keep it within our tolerable limit. Some of the points to reduce air pollutants are stated below-

a) Improve public transportation in large cities and using the public transports instead of private.

b) Timely road maintenance. c) Stopping deforestation; starting landscaping and gardening in the urban areas to promote afforestation/plantation inside the cities to maintain and restore the ecological balance to keep a green clean environment.

d) Improved cooking stoves in rural areas.

e) Air pollution mitigation plan and its enforcement in large construction projects.

f) Import control for quality of coal throughout the country, primarily brick and power industries. 
g) Inspection, maintenance and technology specification of existing steel mills, cement and glass factories.

h) Maintaining the emissions standards at all new plants.

i) Utilizing the alternate construction material (such as ecofriendly bricks instead of soil burned bricks) over the country; especially large cites.

j) Strengthening vehicle inspection and maintenance especially in large cities and completely banning old vehicles which are more than 20 years old.

k) Immediate relocation/shifting the industries (such as tanneries, battery, pharmaceutical, tobacco, brick kilns) away from the residential area and major cities.

l) Establishing and using waste treatment plant in the industries.

m) Using green technology.

n) Understanding the concept of reduce, reuse and recycle.

o) Emphasis on clean energy resources.

p) Practicing the habit of walking and riding bicycle.

q) Using hybrid vehicles and hydrogen fuel cells.

r) Switching off lights, fan, AC etc. when leaving the room.

s) Encouraging research works on environment pollution prevention.

t) Enforcement of existing law regarding environment pollution.

u) Creating public awareness on air pollution through mass media.

\section{Conclusion}

Air pollution is imposing an imminent threat globally in environment, health and crop production sectors. Due to upgradation of living standards, we are polluting the earth more over time. Pollutants like- $\mathrm{CO}, \mathrm{SO}_{\mathrm{x}^{\prime}} \mathrm{NO}_{\mathrm{x}^{\prime}} \mathrm{O}_{3^{\prime}}, \mathrm{Pb}, \mathrm{PM}_{2.5}$ and $\mathrm{PM}_{10}$ were mostly responsible for air pollution. These gaseous pollutants are produced from machine and engines. Health hazards like critical respiratory and pulmonary diseases are associated with these pollutants. Number of patients and deaths were also seen to increase over the years due to different air pollution related diseases. Agriculture production seemed to have both positive and negative effect on crop yields but that depends on the duration, concentration and exposure of the pollutants. Countries like Bangladesh contribute little to air pollution as it emits less amount of carbon in the atmosphere than USA, China etc. industrialized countries. But, in the last few decades massive rice production may have added methane $\left(\mathrm{CH}_{4}\right)$ and ammonia $\left(\mathrm{NH}_{3}\right)$ gases in the atmosphere thereby adding greenhouse gases (GHG).
Since Bangladesh is an over populated country it's of utmost and urgent importance to reduce air pollution by changing the way we live and think; so that we can keep our earth green and clean to breathe for our forthcoming generations.

\section{Acknowledgement}

The author praises utmost thanks and gratitude to N-27th Foundation Training Course for NARS scientist's management authority, National Agriculture Training Academy (NATA), Gazipur, Bangladesh to organize the environment committee and provide scope to play role in the environmental issues and create awareness in NATA campus. Author is also indebted and expresses his sincere appreciation to environment committee members of this course for proposing such a time led topic to review as a part of the seminar presentation during the training course

\section{References}

1. Glueckauf E (1951) The Composition of Atmospheric Air. In: Malone TF (Ed.), Compendium of Meteorology. American Meteorological Society, Boston, MA, pp. 3-10.

2. Felix JR, Anne LD (2006) Air pollution and very low birth weight infants: A target Population. Pediatrics 118(1): 156-164.

3. Davidoff DK (2018) Chapter 3.4 The Greenhouse Effect, Aerosols, and Climate Change. In: Török B, Dransfield T (Eds.), Green Chemistry, Elsevier, pp. 211-234.

4. Gheorghe IF, Ion B (2011) chapter 12 The Effects of Air Pollutants on Vegetation and the Role of Vegetation in Reducing Atmospheric Pollution. In: Khallaf M (Ed.), The Impact of Air Pollution on Health, Economy, Environment and Agricultural Sources, Intech, pp. 241-280.

5. Arden CP, Richard TB, Micheal JT (2002) Lung cancer, cardiopulmonary mortality and long-term exposure to fine particulate air pollution. JAMA 287(9): 1132-1141.

6. Ajayi $\mathrm{AB}$, Dosunmu 00 (2002) Environmental hazards of importing used vehicles into Nigeria. Proceedings of International Symposium on Environmental Pollution Control and Waste Management, pp. 521532.

7. Abam FI, Unachukwu GO (2009) Vehicular emission and air quality standards in Nigeria. European Journal of Scientific Research 34(4): 550-560.

8. Begum BA, Hopke PK (2018) Ambient Air Quality in Dhaka Bangladesh over Two Decades: Impacts of Policy on Air Quality. Aerosol Air Qual Res 18(7): 1910-1920.

9. Roy S, Sowgat T, Mondal J (2019) City Profile: Dhaka, Bangladesh. Environ Urban ASIA 10(2): 216-232.

10. World Population Review (2021) World City Populations 2021.

11. Kojima M, Brandon C, Shah J (2000) Improving urban air quality in south Asia by reducing emissions from two-stroke engine vehicles, The International Bank for Reconstruction and Development/The World Bank.

12. DoE (Department of Environment) (2020) Monthly Air Quality Monitoring Report- Reporting Month: December 2020.

13. Sicard P, Talbot C, Lesne O, Mangin A, Alexandre N, et al. (2012) The Aggregate Risk Index: An intuitive tool providing the health risks of air pollution to health care community and public. Atmospheric Environment 46: 11-16. 
14. Haque HA, Huda N, Tanu FZ, Sultana N, Hossain MSA, et al. (2017) Ambient air quality scenario in and around Dhaka city of Bangladesh. Barisal University Journal Part 1 4(1): 203-218.

15. Plaia A, Ruggieri M (2011) Air quality indices: A Review. Rev Environ Sci Bio-technol 10: 165-179.

16. Iqbal A, Afroze S, Rahman MM (2020) Vehicular PM Emissions and Urban Public Health Sustainability: A Probabilistic Analysis for Dhaka City. Sustainability 12(15): 6284.

17. Agrawal M (2005) Effects of air pollution on agriculture : An issue of national concern. National Academy Science Letters 28(3): 93-106.

18. Nigel J, Bell B, Marshall FM (2002) Effects of Air Pollution on Crops in Developing Countries. In: Ambasht RS, Ambasht NK (Eds.), Modern Trends in Applied Terrestrial Ecology. Springer, Boston, MA.

19. IQAir (2020) World Air Quality Report-Region \& City $\mathrm{PM}_{2.5}$ Ranking.

20. Begum BA, Nasiruddin M, Randal S, Sivertsen B, Hopke PK (2014) Identification and apportionment of sources from air particulate matter at urban environments in Bangladesh. Br J Appl Sci Technol 4(27): 3930-3955.

21. Iqbal A, Allan A, Zito R (2016) Meso-scale on-road vehicle emission inventory approach: A study on Dhaka City of Bangladesh supporting the cause-effect' analysis of the transport system. Environ Monit Assess 188(3): 149.

22. EEA (2009) EMEP/EEA Air Pollutant Emission Inventory Guidebook; European Environment Agency: Luxembourg, 2009.

23. Abdullah S, Mansor AA, Napi NNLM, Mansor WNW, Ahmed AN, et al (2020) Air quality status during 2020 Malaysia Movement Control Order (MCO) due to 2019 novel coronavirus (2019-nCoV) pandemic. Sci Total Environ 729: 139022.

24. Otmani A, Benchrif A, Tahri M, Bounakhla M, Chakir EM, et al. (2020) Impact of Covid-19 lockdown on $\mathrm{PM}_{10}, \mathrm{SO}_{2}$ and $\mathrm{NO}_{2}$ concentrations in Salé City (Morocco). Sci Total Environ 735: 139541.

25. Wang Y, Yuan Y, Wang Q, Liu C, Zhi Q, et al. (2020) Changes in air quality related to the control of coronavirus in China: Implications for traffic and industrial emissions. Sci Total Environ 731: 139133.

26. Islam MM, Afrin S (2014) Air quality status of dhaka city and effects of seasons, weekends, eid and hartal days. $2^{\text {nd }}$ International Conference on Advances in Civil Engineering (ICACE-2014). 26 -28 December, CUET, Chittagong, Bangladesh.

27. Rahman MM, Mahamud S, Thurston GD (2019) Recent spatial gradients and time trends in Dhaka, Bangladesh, air pollution and their human health implications. Journal of the Air \& Waste Management Association 69(4): 478-501.

28. DoE (Department of Environment) (2012) Air Pollution Reduction Strategy for Bangladesh. pp. 16-74.
29. Manisalidis I, Stavropoulou E, Stavropoulos A, Bezirtzoglou E (2020) Environmental and Health Impacts of Air Pollution: A Review. Front Public Health 8: 14.

30. Sætterstrøm B, Kruse M, Hansen HB, Bønløkke JH, Flachs EM, et al. (2012) A Method to Assess the Potential Effects of Air Pollution Mitigation on Healthcare Costs. Journal of Environmental and Public Health 2012: 935825

31. Alam MZ, Armin E, Haque M, Halsey J, Kayesh E, et al. (2018) Air Pollutants and their Possible Health Effects at Different Locations in Dhaka City. Int J Environ Sci Nat Res 9(4): 555768.

32. WHO (2014) 7 million premature deaths annually linked to air pollution.

33. Hsu WH, Hwang SA, Kinney PL, Lin S (2017) Seasonal and temperature modifications of the association between fine particulate air pollution and cardiovascular hospitalization in New York State. Sci Total Environ 578: 626-632.

34. Mamun MA, Rumana N, Pervin K, Azad MC, Shahana N, et al. (2015) Emerging burden of cardiovascular diseases in Bangladesh. J Atheroscler Thromb 23(4): 365-375.

35. Roser HR (2018) Causes of death.

36. IHME (2018) Global Burden of Disease Study 2016 (GBD 2016) data resources.

37. Health Effects Institute (2017) State of Global Air 2017.

38. The Sustainable Food Trust (2019) The impact of air pollution on crops.

39. Devrajani SK, Qureshi M, Imran U, Nisa TUI (2020) Impact of Gaseous Air Pollutants on Agricultural Crops in Developing Countries: A review. Journal of Environmental Science and Public Health 4 (2020): 71-82.

40. Eris G, Lyu C, Swartwood N (2016) Air Pollution Effects on Rice Yields in South Asia.

41. Schiferl LD, Heald CL, Kelly D (2018) Resource and physiological constraints on global crop production enhancements from atmospheric particulate matter and nitrogen deposition. Biogeosciences 15: 43014315.

42. Beig G (2013) Impact of air pollution on agriculture.

43. Chowhan S, Ghosh S, Chowhan T, Hasan MM, Roni MS (2016) Climate change and crop production challenges: An overview. Research in Agriculture Livestock and Fisheries 3(2): 251-269. 
(CC) Commons Attribution 4.0 License

(c) DOI:10.19080/IJESNR.2021.28.556231
Your next submission with Juniper Publishers will reach you the below assets

- Quality Editorial service

- Swift Peer Review

- Reprints availability

- E-prints Service

- Manuscript Podcast for convenient understanding

- Global attainment for your research

- Manuscript accessibility in different formats ( Pdf, E-pub, Full Text, Audio)

- Unceasing customer service

Track the below URL for one-step submission https://juniperpublishers.com/online-submission.php 